\title{
PENGARUH ATRIBUT PRODUK YANG DIPERTIMBANGKAN DALAM PEMILIHAN PRODUK DEPOSITO PERBANKAN TERHADAP KEPERCAYAAN DAN DAMPAKNYA PADA LOYALITAS NASABAH
}

\author{
Gunarto Suhardi \\ Fakultas Hukum Universitas Atma Jaya Yogyakarta
}

\begin{abstract}
Trust is the critical element in banking product. Without consumer trust, banking industry will face a difficulties to create a true loyalty. Attribute product can help banking industry to create consumer trust by creating a product which has an important attribute by which consumer make a consideration whether the bank is credible or not. The aim of this research is to find out attribute that is important in consumer persepective and how would those attribute affecting their trust and their loyalties to the bank. Exploratory factor analysis was used to find the most important attribute product. The exploratory factor analysis result then analyized with structural equation modeling to calculate the effect of the important attribute to the consumer trust and loyalty. As a result, they are 2 factor which are Flexibility factor and Bank Competencies factor as an important attribute product which has affected trust and loyalty as well.
\end{abstract}

Keywords : trust, banking, attribute product, loyalty, deposito

\section{PENDAHULUAN}

Sesuai bunyi pasal 4 Undang Undang No 7 Tahun 1992 dan Undang Undang No 10 Tahun 1998 perbankan Indonesia bertujuan menunjang pelaksanaan pembangunan nasional dalam rangka meningkatkan pemerataan, pertumbuhan ekonomi dan stabilitas nasional kearah peningkatan kesejahteraan rakyat banyak. Pasal 1 juga menyatakan bahwa fungsi utama perbankan adalah menghimpun dan menyalurkan dana kepada masyarakat.

Untuk melaksanakan fungsi itu maka langkah pertama adalah bank harus mampu menghimpun dana dengan terus menarik nasabah untuk menempatkan dananya pada bank terutama yang berjangka panjang berupa deposito. Dengan demikian, Bank harus memahami pengaruh atribut produk yang dipertimbangkan dalam pemilihan produk deposito perbankan terhadap kepercayaan dan dampaknya pada loyitas nasabah.

Perlu juga diperhatikan bahwa kasus ini mempunyai keterkaitan dengan kejadian dan dampaknya secara luas pada fungsi perbankan ketika pertumbuhan ekonomi dan kesejahteraan rakyat, terutama dalam kondisi ekonomi Indonesia yang senyatanya sedang menurun terutama dalam kasus produktivitas bangsa. Sebagaimana tertulis dalam Undang Undang yang ditujukan pada masyarakat perbankan maka tugas meningkatkan produktivitas bangsa melalui pembiayaan oleh perbankan adalah tugas yang paling menentukan bagi kelangsungan bangsa Indonesia. Tugas ini hanya dapat tercapai apabila tugas penghimpunan dana berhasil dilakukan dengan baik.

Saat ini konsumen perbankan dalam menyimpan dana berbentuk deposito pada bank sangat berbeda dengan dekade sebelumnya. Konsumen perbankan tidak lagi menjadi pihak yang terabaikan. Bahkan dalam beberapa industri lainnya, konsumen menjadi penentu kelangsungan hidup perusahaan. Bukan sesuatu yang aneh ketika perusahaan menutup usahanya karena tidak terdapat cukup pelanggan yang menguntungkan. Beberapa ahli berpendapat bahwa biaya yang harus dikeluarkan untuk memperoleh pelanggan baru lebih mahal 5 kali dibandingkan dengan biaya yang harus dikeluarkan untuk mempertahankan konsumen yang sudah ada. 
Dunia perbankan saat ini banyak diwarnai oleh berbagai produk baru disamping produk-produk investasi konvensional yang telah ada. Saat ini begitu banyak bentuk investasi yang ditawarkan pada masyarakat. Terdapat manajemen dana nasabah yang dikenal dengan sebutan reksadana, asuransi, manajemen asset, lembaga pengelolaan investasi saham dan mata uang asing. Produk-produk ini sebenarnya merupakan derivatif dari produk perbankan lama dan merupakan pengembangan dari tugas yang dibebankan oleh kedua Undang Undang itu. Jasa keuangan semacam ini terbilang unik karena memiliki karakteristik yang unik dibandingkan dengan produk lain. Elemen-elemen yang abstrak turut mewarnai hubungan antara konsumen dalam hal ini nasabah dengan pihak bank Dalam produk yang mengandalkan hubungan antara konsumen dan penyedia jasa maka kepercayaan menjadi hal yang mendasar bagi kinerja bank dan sangat menentukan kelangsungan usaha bank yang bersangkutan .

Seiring dengan semakin bervariasinya tawaran produk-produk jasa keuangan di pasar maka saat ini terdapat kecenderungan bahwa deposito atau tabungan tidak lagi menjadi produk investasi satu-satunya bagi konsumen yang memiliki kelebihan dana dan menginginkan tingkat pengembalian yang tinggi atas investasinya. Kecenderungan ini menggambarkan kompleksitas konsumen dalam pengambilan keputusan dalam produk jasa investasi karena keputusan investasi merupakan keputusan diantara risiko dan keuntungan atau dengan kata lain terdapat imbangan antara kenyataannya bahwa makin besar resiko juga makin besar juga hasil bunganya.

Produk investasi merupakan salah satu produk yang memiliki risiko tersendiri . Sementara di pihak lain, proses keputusan konsumen tidak semata-mata ditentukan oleh harga atau hasil dari produk itu saja. Terdapat pula aspek-aspek lain dari produk yang dipertimbangkan oleh konsumen dalam proses pengambilan keputusannya. Penelitian ini bermaksud untuk menemukan atribut produk yang dipertimbangkan nasabah dalam memilih deposito sebagai produk yang ditawarkan oleh perbankan sebagai bentúk investasi dan pengaruhnya terhadap kepercayaan dan loyalitas nasabah.

\section{TINJAUAN LITERATUR}

Loyalitas merupakan komitmen mendalam secara psikologis untuk melakukan pembelian ulang dimasa mendatang. Berbeda dengan pembelian ulang biasa, dalam konsep ini pembelian ulang produk dilakukan atas dorongan komitmen yang sangat mendalam. Bahkan secara singkat, loyalitas merupakan komitmen mendalam konsumen untuk melakukan pembelian ulang produk atau jasa secara konsistem di masa depan meskipun terdapat tawaran menarik dari pesaing untuk berpindah merek (Oliver (1999), Bloemer \& Marthens (1995). Konsep loyalitas menurut Oliver, menyatakan bahwa tingkat loyalitas konsumen terdiri dari 3 tahap (dalam Costabile, 2000 ) yakni

- Cognitively Loyal

Tahap dimana konsumen memiliki pengetahuan langsung maupun tidak langsung konsumen terhadap merek, manfaatnya, dan dilanjutkan dengan melakukan pembelian berdasarkan keyakinan akan superioritas yang ditawarkan.

- $\quad$ Affectively Loyal

Sikap favorable konsumen terhadap merek yang merupakan hasil konfirmasi berulang dari harapannya selama tahap cognitively loyal berlangsung.

- Conatively Loyal

Intensi membeli ulang sangat kuat dan memiliki keterlibatan tinggi yang merupakan dorongan motivasi.

- Action Loyal

Loyalitas yang bertahan tidak saja karena motivasi yang kuat semata namun telah menjadi suatu keinginan untuk mengatasi segala hambatan yang menghalangi konsumen membeli merek tertentu

Hubungan yang didasarkan atas komitmen yang mendalam semacam ini merupakan hubungan yang dekat dimana hubungan dekat ini memerlukan kondisi yang lebih stabil, lebih mudah bagi setiap pihak untuk saling memperkirakan perilaku patner (Turnbull et al., dalam Bennet dan Gabriel, 2001). Kepercayaan merupakan determinan hubungan semacam ini karena kepercayaan merupakan wujud keyakinan bahwa pihak lain tidak akan 
memanfaatkan kelemahan patnernya ( misbruik van omstandigheiden ). Dengan kata lain, masing-masing pihak memiliki keyakinan akan keandalan dan integritas masing-masing (Morgan \& Hunt, 1994)

Demikian Menurut Achroll (dalam Bennet dan Gabriel, 2003) dalam dunia bisnis, kepercayaan antar perusahaan (buyer-seller) membantu dalam menentukan indikator-indikator yang berkaitan dengan kinerja seperti jangkauan pertukaran informasi, penyelesain masalah bersama, kepuasan atas hasil-hasil aktivitas yang telah dilakukan dan semakin besarnya motivasi dalam implementasi hasil-hasil keputusan. Adanya kepercayaan akan menciptakan rasa aman dan kredibel dan mengurangi persepsi konsumen akan risiko dalam pertukaran (Selnes, 1988 dalam Bennet dan Gabriel, 2003).

Menurut Luarn dan Lin (2003) kepercayaan adalah sejumlah keyakinan spesifik terhadap integritas (kejujuran pihak yang dipercaya dan kemampuan menepati janji), benevolence (perhatian dan motivasi yang dipercaya untuk bertindak sesuai dengan kepentingan yang mempercayai mereka atau dewngan kata sederhana adalah itikad baik), competency (kemampuan pihak yang dipercaya untuk melaksanakan kebutuhan yang mempercayai) dan predictability (konsistensi perilaku pihak yang dipercaya). Costabile (1998) berpendapat bahwa kepercayaan merupakan persepsi akan kehandalan dari sudut pandang konsumen didasarkan pada pengalaman pribadinya

Salah satu sarana bagi konsumen untuk menilai keandalan dan integritas patner dalam pertukaran adalah atribut produk. Menurut Kotler dan Armstrong atribut produk bertugas untuk mengkomunikasikan dan menghantarkan manfaat inti (core benefit) yang ingin disampaikan produk kepada konsumen. Beberapa atribut yang terkandung biasanya memiliki perbedaan dengan produk-produk yang sejenis. Mungkin dalam hal nama merek ( deposito dan bank penerbitnya ), harga yang lebih mahal atau murah, kemasan yang lebih menarik, atau komposisi yang berbeda (Ferrinadewi dan Darmawan, 2004). Atribut produk merupakan sesuatu yang dinilai oleh konsumen dalam menentukan relevansi dirinya dengan produk. Oleh karena itu, bertanya kepada konsumen atribut mana yang dianggap penting merupakan cara yang tepat untuk mengetahui pertimbangan keputusan pembelian konsumen (Oliver, 1997).

\section{METODA PENELITIAN}

Sesuai dengan maksud dari penelitian ini, maka terdapat beberapa langkah dalam penelitian ini. Langkah pertama, nasabah diminta untuk mengidentifikasi atribut produk yang menjadi pertimbangan dalam memutuskan produk deposito bank mana yang dipercaya sebagai alat investasinya. Selanjutnya hasil identifikasi tersebut dikelompokkan menjadi beberapa faktor (exploratory factors) dan selanjutnya dianalisis dengan persamaan struktural untuk melihat pengaruhnya pada kepercayaan dan loyalitas nasabah.

Selanjutnya faktor yang ditemukan tersebut diteliti pengaruhnya terhadap kepercayaan nasabah pada bank dan dampaknya terhadap loyalitas mereka. Berdasarkan tinjauan diatas, maka dapat dibangun kerangka penelitian dengan beberapa dugaan yang dinyatakan dalam hipotesis alternatif sebagai berikut :

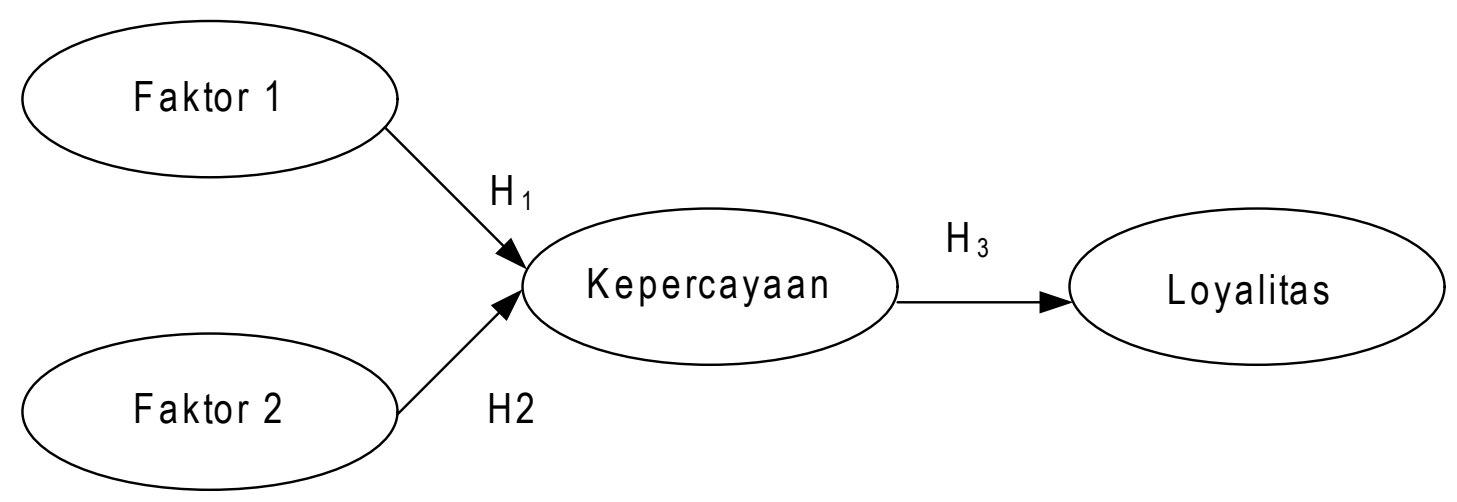

\section{Gambar 1 \\ Kerangka Penelitan}


$\mathrm{H}_{1}=$ faktor 1 mempengaruhi kepercayaan nasabah pada bank secara signifikan

$\mathrm{H}_{2}=$ faktor 2 mempengaruhi kepercayaan nasabah pada bank secara signifikan

$\mathrm{H}_{3}=$ kepercayaan nasabah pada bank mempengaruhi loyalitasnya secara signifikan

Sebanyak 220 responden yang menetap di Surabaya dan merupakan nasabah beberapa bank di surabaya yang memiliki simpanan deposito berjangka, diminta mengisi kuesioner terstruktur yang berisi pertanyaan penilaian mereka terhadap atribut produk yang dipertimbangkan dalam keputusan penempatan dananya. Data untuk identifikasi atribut dikumpulkan dengan penggunaan skala Likert 1 - 5 dimana 1 mewakili sangat penting dan 5 mewakili sangat tidak penting. Data dikumpulkan periode Januari - April 2007. Sampel diambil dengan menggunakan teknik random sampling di beberapa bank di Surabaya dengan memegang prinsip kerahasiaan nasabah. Sampel adalah nasabah bank pemerintah maupun swasta di Surabaya yang memiliki deposito berjangka selama periode penelitian berlangsung, berdomisili dan bekerja di Surabaya dan telah menjadi nasabah bank yang bersangkutan lebih dari 5 tahun.

Dalam penelitian ini, indikator yang digunakan untuk mengukur kepercayaan merek adalah indicator yang digunakan oleh Luarn dan Lin (2003) yaitu benevolence (perhatian dan motivasi yang dipercaya untuk bertindak sesuai dengan kepentingan yang mempercayai mereka), competency (kemampuan pihak yang dipercaya untuk melaksanakan kebutuhan yang mempercayai) dan predictability (konsistensi perilaku pihak yang dipercaya).

Sementara untuk loyalitas, indikator yang digunakan untukkmengukurvariabel ini adalah studi ini menggunakan pendapat Oliver (dalam Costabile, 2000) yaitu kesetiaan secara kognitif, afektif, konatif dan kesetiaan tindakan.

\section{HASIL ANALISIS DAN PEMBAHASAN}

Hasil focus group yang dilakukan pada 50 nasabah dari berbagai bank di Surabaya, berhasil mengidentifikasikan 10 atribut produk yang dipertimbangkan dalam memilih produk deposito yaitu :

(1) Tingkat keamanan yang lebih tinggi dari pada sarana investasi lainnya karena bank diawasi oleh Bank Indonesia dengan ketat

(2) Kemudahan akses produk perbankan karena cabang perbankan ada dimana saja bahkan sampai ke unit desa dipelosok tanah air

(3) Tingginya tingkat bunga yang ditawarkan yakni berada tepat dibawah Sertifikat Bank Indonesia

(4) Bervariasinya pilihan jangka waktu ( 1 bulan, 3 bulan, 6 bulan, setahun dan 2 tahun)

(5) Fasilitas untuk jaminan bila yang bersangkutann ingin memperoleh kredit dari bank (cash collateral)

(6) Bisa dicairkan dengan atau tanpa pinalti (tergantung penawaran bank yang bersangkutan)

(7) Kerahasiaan identitas nasabah (dijamin oleh Undang Undang)

(8) Minimal dana setoran yang makin rendah,

(9) Image bank yang makin membaik

(10) Prosedur aplikasi sederhana yang telah dibakukan

(11) Teknologi pelayanan yang makin maju dengan ATM maupun SMS Banking.

Faktor 1 menjelaskan 44\% dari total varian, dan diberi nama faktor Fleksibilitas sementara faktor ke 2 yang menjelaskan $29.3 \%$ dari total varian diberi nama faktor Kompetensi bank.

Uji reliabilitas untuk Faktor Kompetensi Bank sebesar 0.91, untuk Faktor Fleksibilitas sebesar 0.90, semuanya diatas nilai The Cronbach'Alpha yang diterima secara umum yaitu diatas 0.70 sehingga dapat dikatakan ke 2 faktor diatas diperoleh dengan alat yang reliabel. Selanjutnya akan dibahas pengaruh kedua factor tersebut terhadap tingkat kepercayaan nasabah terhadap perbankan dan dampaknya pada loyalitas nasabah. 
Tabel 1

Atribut Produk Deposito yang Dipertimbangkan

\begin{tabular}{lll}
\hline \multicolumn{1}{c}{ Atribut Produk } & \multicolumn{2}{c}{ Faktor } \\
\hline Fasilitas sbg jaminan pinjaman & .788 \\
Pilihan jangka waktu & .793 & \\
Minimal jumlah simpanan & .817 & \\
Mudah dicairkan & .803 & \\
Keamanan & & .750 \\
Citra bank & .804 \\
Mudah diakses nasabah & .783 \\
Jaminan kerahasiaan identitas & .823 \\
Tingkat bunga & & \\
Prosedur sederhana & .830 \\
\hline
\end{tabular}

Selanjutnya kedua faktor tersebut dilihat pengaruhnya terhadap kepercayaan dan dampaknya loyalitas nasabah dengan persamaan structural. Data yang diperoleh memenuhi syarat untuk diproses lebih lanjut dalam arti distribusi datanya normal, tidak ada outlier dan tidak terdapat multikolinearitas serta singularity. Uji terhadap model penelitian menunjukkan bahwa model tersebut sesuai dengan data yang digunakan

Tabel 2

Goodness of Fit Indices

\begin{tabular}{|c|c|c|c|}
\hline Goodness of fit Index & $\begin{array}{l}\text { Cut off } \\
\text { Value }\end{array}$ & $\begin{array}{c}\text { Hasil } \\
\text { Penelitian }\end{array}$ & Evaluasi \\
\hline $\mathrm{X}^{2}$ Chi Square & & 131.276 & Baik \\
\hline Significancy Prob. & $>0.05$ & 0.142 & Baik \\
\hline RMSEA & $<0.08$ & 0.025 & Baik \\
\hline GFI & $>0.90$ & 0.936 & Baik \\
\hline CFI & $>0.95$ & 0.993 & Baik \\
\hline TLI & $>0.90$ & 0.994 & Baik \\
\hline CMIN/DF & $<2.00$ & 1.142 & Baik \\
\hline
\end{tabular}




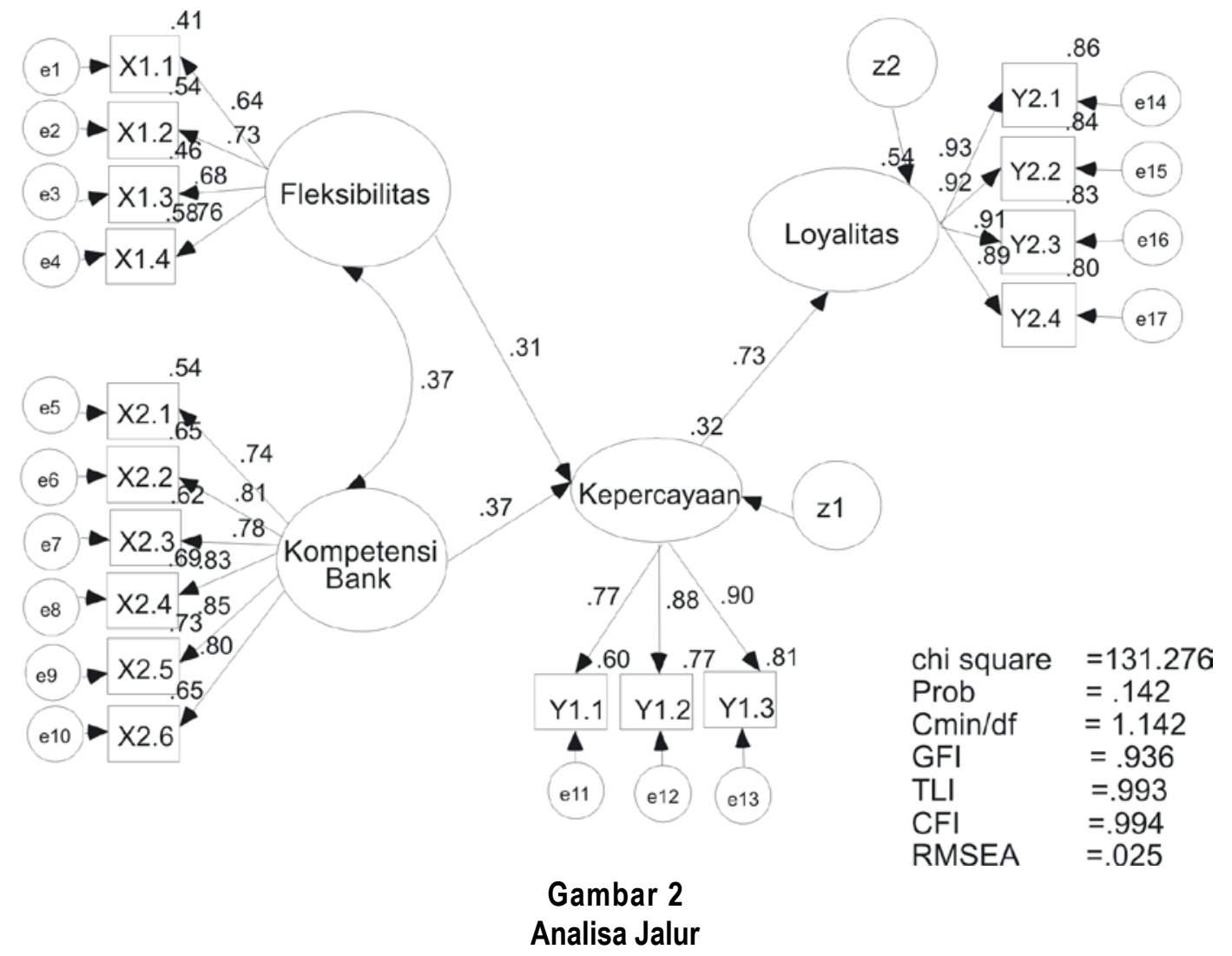

Pengujian hipotesis 1 bahwa faktor pertama yaitu faktor fleksibilitas terbukti mempengaruhi kepercayaan nasabah pada bank secara signifikan dengan nilai critical ratio sebesar 3.683 dan taraf signifikansinya dibawah 0.05. Sementara hipotesis 2 bahwa faktor kedua yaitu kompetensi bank terbukti mempengaruhi kepercayaan nasabah dengan critical ratio sebesar 4.904 dan taraf signifikansi dibawah 0.05 . Hipotesis ketiga bahwa kepercayaan nasabah mempengaruhi loyalitas nasabah terbukti secara signifikan dengan nilai critical ratio sebesar $10.655(<0.05)$.

Tabel 3

Bobot Regresi dan Pengujian Hipotesis

\begin{tabular}{llrrrr}
\hline & & Estimate & S.E. & C.R. & P \\
\hline Kepercayaan & $\leftarrow$ Kompetensi_Bank & .384 & .078 & 4.904 & $* * *$ \\
Kepercayaan & $\leftarrow$ Fleksibilitas & .374 & .102 & 3.683 & $* * *$ \\
Loyalitas & $\leftarrow$ Kepercayaan & .815 & .077 & 10.655 & $* * *$ \\
x1.2 & $\leftarrow$ Fleksibilitas & 1.147 & .135 & 8.530 & $* * *$ \\
x2.1 & $\leftarrow$ Kompetensi_Bank & 1.000 & & & \\
x2.2 & $\leftarrow$ Kompetensi_Bank & 1.023 & .086 & 11.957 & $* * *$ \\
x2.3 & $\leftarrow$ Kompetensi_Bank & .959 & .083 & 11.501 & $* * *$ \\
x2.4 & $\leftarrow$ Kompetensi_Bank & 1.004 & .081 & 12.378 & $* * *$ \\
x2.5 & $\leftarrow$ Kompetensi_Bank & 1.025 & .082 & 12.576 & $* * *$ \\
x2.6 & $\leftarrow$ Kompetensi_Bank & 1.007 & .085 & 11.841 & $* * *$ \\
x1.1 & $\leftarrow$ Fleksibilitas & 1.000 & & & \\
x1.3 & $\leftarrow$ Fleksibilitas & 1.015 & .131 & 7.722 & $* * *$
\end{tabular}




\begin{tabular}{llrrrr}
\hline $\mathrm{x} 1.4$ & $\leftarrow$ Fleksibilitas & 1.238 & .151 & 8.176 & $* * *$ \\
y1.3 & $\leftarrow$ Kepercayaan & 1.104 & .079 & 14.035 & $* * *$ \\
y1.1 & $\leftarrow$ Kepercayaan & 1.000 & & & \\
y1.2 & $\leftarrow$ Kepercayaan & .992 & .071 & 13.877 & $* * *$ \\
y2.2 & $\leftarrow$ Loyalitas & .968 & .041 & 23.662 & $* * *$ \\
y2.1 & $\leftarrow$ Loyalitas & 1.000 & & & \\
y2.4 & $\leftarrow$ Loyalitas & 1.051 & .048 & 21.810 & $* * *$
\end{tabular}

\section{PEMBAHASAN}

Berdasarkan analisa jalur diatas dapat diketahui bahwa pengaruh faktor Kompetensi bank memiliki pengaruh sebesar $37 \%$ terhadap kepercayaan nasabah pada bank, dan ini lebih besar daripada pengaruh fleksibilitas yang hanya sebesar $30.8 \%$.

Kompetensi bank yang terdiri dari keamanan, citra bank, mudah diakses nasabah, jaminan kerahasian identitas, tingkat bunga dan prosedur pembukaan deposito yang mudah memberikan dampak yang besar pada loyalitas nasabah sebesar $31.3 \%$.

Faktor Fleksibilitas yang terdiri dari fasilitas sebagai jaminan pinjaman, pilihan jangka waktu, minimal dana yang disimpan dan kemudahan untuk pencairan memberikan dampak tidak langsung terhadap loyalitas sebesar $30.5 \%$

Meskipun survey ini dilakukan di Surabaya akan tetapi nampaknya hal ini menjadi pola nasional berdasarkan dua alasan pokok yakni:

1. Kota Surabaya sebagai kota terbesar kedua di Indonesia dimana pengaruh individu perseorangan dan pengaruh perusahan masih dalam imbangan wajar ( vide Laporan 4 Wilker Bank Indonesia Jawa Timur periode 2005 ). Pada umunya perorangan menempatkan kelabihan dananya pada bank terpercaya berdasarkan perhitungan keamanan dan tingginya suku bunga dibandingkan dengan penempatan lainnya. Menurut laporan BI Wilker Surabaya sejak tahun 2000 telah terjadi pergeseran simpanan deposito dari jangka pendek kejangka menengah dan panjang karena kebutuhan pendanaan dunia usaha telah berubah kearah jangka lebih panjang dan karena faktor kepercayaan yang tinggi pada perbankan nasional. Simpanan perbankan jangka panjang tentu saja dapat difasilitasi produk perbankan berupa Deposito Berjangka yang total dananya di Jawa Timur rata mencapai 2 ( dua ) kali lipat dari sarana simpanan berupa tabungan dan 3 ( tiga ) kali lipat dana berbentuk Giro ( vide Kajian Ekonomi Regional Jawa Timur Triwulan IV/2000 yang diterbitkan Bank Indonesia Surabaya )

2. Dari Laporan Statistik Ekonomi Keuangan Indonesia yang diterbitkan Bank Indonesia pusat 2007 (vide www. bi.go.id) dapat diambil kesimpulan yang hampir sama bahwa faktor keuntungan dan kepercayaan menjadi alasan mengapa simpanan deposito dan tabungan yang berjangka lebih panjang dari Giro tetap menunjukkan angka yang cukup tinggi. Sayang bahwa dalam laporan itu masih diadakan penggabungan antara simpanan berjangka ( deposito) dengan simpanan berupa tabungan. Meskipun demikian dengan melihat laporan Wilker BI di Jawa Timur dapat diambil pedoman bahwa secara nasionalpun total saldo deposito nasional masih 2 ( dua ) kali lipat simpanan berupa tabungan.

Dari laporan Bank Indonesia pusat akhir tahun 2007 itu dapat disajikan data saldo penghimpunan dana secara nasional Dalam Miliar Rupiah pada tabel 4 sebagai berikut : 


\begin{tabular}{lccc}
\multicolumn{5}{c}{ Tabel 4 } \\
\multicolumn{4}{c}{ Data Saldo } \\
& $\begin{array}{c}\text { Penghimpunan Dana Secara Nasional } \\
\text { (dalam milliar rupiah) } \\
\text { Dana Giro }\end{array}$ & $\begin{array}{c}\text { Simpanan Berjangka/ } \\
\text { Periode }\end{array}$ & Kredit \\
& & Tabungan & \\
Januari & 214.105 & 835.492 & 739.695 \\
Februari & 218.108 & 842.238 & 749.775 \\
Maret & 212.088 & 848.830 & 763.756 \\
April & 219.438 & 844.469 & 777.349 \\
Mei & 215.020 & 836.311 & 786.051 \\
Juni & 234.406 & 857.973 & 815.369 \\
Juli & 253.412 & 867.310 & 826.194 \\
Agustus & 252.630 & 878.493 & 846.472 \\
September & 250.714 & 883.999 & 866.979 \\
Oktober & 257.786 & 896.450 & 884.017 \\
November & 262.910 & 912.979 & 908.339 \\
Desember & 277.141 & 966.392 & 944.074 \\
Sumber: Bank Indonesia (diolah) & &
\end{tabular}

Hal lainnya dalam menganalisa dana deposito yang kiranya perlu mendapat catatan atau perhatian adalah antara lain:

1. Daya pengendapan dana :

Baik dana giro dan lebih-lebih deposito mempunyai daya peengendapan yang stabil bahkan terus meningkat dari bulan kebulan bahkan dari laporan Bank Indonesia juga dari tahun ke tahun. Daya pengendapan ini penting karena berhubungan langsung dengan kemampuan bank umum untuk memberikan fasilitas kredit kepada nasabah debiturnya yang pada umumnya cenderung untuk memakai fasilitas kredit ini dalam jangka lebih dari satu tahun ( perpanjangan tiap tahun ) .

Bila daya pengendapan pendek dan tidak stabil maka niscaya akan terjadi missmatch yang akan memberikan pengaruh buruk bagi kesehatan bank umum. Prinsip yang harus dipegang dalam usaha perbankan adalah dana dengan jangka waktu pengendapan pendek harus ditempatkan dalam sisi aktiva yang pendek pula. Ini menimbulkan dilema karena usaha produksi biasanya memerlukan jangka waktu menengah bahkan untuk investasi harus dibiayai oleh dana kredit investasi yang berjangka panjang.

Oleh karena itu maka opsi untuk memberikan kredit jangka menengah atau panjang haruslah dihadapi dengan strategi untuk memperoleh dana simpanan masyarakat yang berjangka panjang misalnya deposito berjangka.

2. Juridically predictable.

Meskipun terdapat daya pengendapan yang stabil pada semua jenis dana pada kondisi ekonomi negara yang normal akan tetapi dana deposito adalah satu-satunya yang secara juridis dapat dipastikan jangka pengendapannya. Certainty dan oleh karena itu predictibility adalah unsur terpenting dalam usaha industri dan trading. Kedua unsur ini hanya dapat diberikan secara jelas oleh usaha pengumpulan dana dalam bentuk deposito perbankan.

3. Pengaruh pasar finansial.

Bagi mereka yang memahami situasi pasar keuangan ( financial market) tentu mengetahui bahwa investasi dalam pasar modal mengandung resiko yang lebih besar karena meskipun sering terjadi rebound pada saat terjadi gejolak pasar modal akan tetapi sering juga meninggalkan bilur-bilur kerugian pada pemilik modal. Sebaliknya krisis perbankan ( mass bank failure ) tidak sering bahkan hampir tidak pernah terjadi pada seluruh wilayah pasar keuangan. Regional crisis mungkin terjadi akan tetapi tidak meliputi seluruh dunia sekaligus seperti krisis tahun 1998 hanyalah terjadi di Asia. 


\section{Konstribusinya :}

Konstribusi deposito terhadap keseluruhan usaha pengumpulan dana perbankan juga cukup besar bahkan boleh dikatakan paling besar. Ini juga menunjukkan bahwa motivasi penyimpan dana makin jelas yakni untuk memperoleh keamanan ( trust ) bagi dananya dan perolehan hasil bunga yang cukup tinggi. Pada dana giro sebenarnya motivasi penyimpan hanyalah kepercayaan dan kelancaran dalam penarikannya sehingga dimaksudkan bukan untuk "menyimpan" dananya akan tetapi hanyalah untuk memperlancar transaksi usahanya saja.

\section{PENUTUP}

Stability, pricditybility dan sustainability penyediaan dana perbankan berkat kepercayaan para nasabah bank pada produk deposito pada gilirannya juga mempunyai pengaruh yang amat besar bagi jalannya usaha produksi pada ekonomi riil. Tanpa usaha produksi riil maka tugas negara untuk menyediakan dan menjaga kelangsungan kesempatan kerja bagi seluruh penduduk Indonesia juga tidak dap[at diolaksanakan dengan baik. Kesempatan kerja merupakan kunci pokok dalam memenuhi tugas negara sesuai konstitusi yakni memberikan kesejahteraan bagi seluruh Rakyat Indonesia.

Kesempatan kerja dan pemberian kemakmuran bagi rakyat masih sepenuhnya bergantung kepada kebijaksanaan keuangan negara dan kebijaksanaan dalam reksa pemerintahan lainnya termasuk dalam penyediaan infrastruktur dan penyediaan energi nasional akan tetapi sekurang-kurangnya masyarakat perbankan sudah memberikan konstribusi yang amat penting. Konstribusi inilah yang juga diharapkan oleh Undang Undang No 7 Tahun 1992 dan Undang Undang No 10 Tahun 1998 ketika membahas tentang tujuan, fungsi dan peranan bank di Indonesia sebagaimana disebutkan dalam pasal 4 Undang Undang tersebut yakni "Perbankan di Indonesia bertujuan menunjang pelaksanaan pembangunan nasional dalam rangka meningkatkan pemerataan, pertumbuhan ekonomi dan stabilitas nasional kearah peningkatan kesejahteraan rakyat banyak".

Keterbatasan penelitian ini adalah sampel yang digunakan hanya terbatas pada daerah Surabaya sehingga bersifat regional. Akan tetapi dengan dukungan data perbankan secara umum, keterbatasan tersebut masih dapat ditanggulangi. Untuk penelitian selanjutnya, dapat mengkaji masalah ini ke seluruh wilayah Indonesia dengan populasi yang lebih luas lagi sehingga hasil penelitian dapat lebih valid.

\section{DAFTAR PUSTAKA}

Bennet, Roger \& Helen Gabriel, (2001), "Reputation, Trust and Supplier Commitment the Case of Shipping Company/seaport Relations", Journal of Business and Industrial Marketing, Vol. 16 pp. 424-438.

Bloemer, Josée, Gaby Oderkeken-Schröder, \& Hilda Martens, (2003), "The Pshychology Behind Commitment and Loyalty : An Empirical Study in The Banking Industry", University Nijmegen, Netherland.

Costabile, Michele, (2003), A Dynamic Model of Customer Loyalty, Paper, www.watoowatoo.com.

Ferrinadewi, Erna \& Didit Darmawan, (2004), Perilaku Konsumen : Analisis Model Keputusan, Universitas Atmajaya Press, Yogyakarta.

Kotler, Philip \& Gary Armstrong, (1999), Principle of Marketing, $8^{\text {th }}$ edition, Prentice Hall, New Jersey.

Luarn, Pin \& Hsin-Hui lin, (2003), "A Customer Loyalty Model For E Service Context", Journal of Electronic Commerce Research, Vol. 4, no. 4, pp. 156-167.

Morgan, Robert M. \& Shelby D. Hunt, (1994), "The Commitment -Trust Theory of Relationship Marketing" Journal of Marketing, Vol. 58, pp. 20-38.

Martia Stigum, (1983), The Money Market, Dow Jones-Irwin, Homewood Illinois 60430. 
Martia Stigum, (1983), Managing Bank Assets and Liabilities, Dow Jones - Irwin.

Oliver, Richard L, (1999), "Whence Loyalty”, Journal of Marketing, Special Issues, Vol 63, pp.33-44.

Selnes, Fred, (1993), "An Examinantion of The Effect of Product Perfomance on Brand Reputation, Satisfaction \& Loyalty", European Journal of Marketing, Vol 27, no. 9, pp. 19-35.

Suhardi Gunarto,(2003), Usaha Perbankan Dalam Perspektif Hukum ,Penerbit Kanisius Yogyakarta. 